\title{
Lysine Supply Is a Critical Factor in Achieving Sustainable Global Protein Economy
}

\author{
Ilkka Leinonen ${ }^{1 *}$, Pietro P. M. lannetta ${ }^{2}$, Robert M. Rees $^{3}$, Wendy Russell ${ }^{4}$, \\ Christine Watson ${ }^{5}$ and Andrew P. Barnes ${ }^{1}$ \\ ${ }^{1}$ Department of Rural Economy, Environment \& Society, Scotland's Rural College (SRUC), Edinburgh, United Kingdom, \\ ${ }^{2}$ Ecological Sciences, James Hutton Institute, Dundee, United Kingdom, ${ }^{3}$ Carbon Management Centre, Scotland's Rural \\ College (SRUC), Edinburgh, United Kingdom, ${ }^{4}$ Rowett Institute of Nutrition and Health, University of Aberdeen, Aberdeen, \\ United Kingdom, ${ }^{5}$ Crop and Soil Systems, Scotland's Rural College (SRUC), Aberdeen, United Kingdom
}

\section{OPEN ACCESS}

Edited by:

Rakesh Bhardwaj,

National Bureau of Plant Genetic Resources (ICAR), India

Reviewed by:

Somnath Mandal, Uttar Banga Krishi Viswavidyalaya,

R. Ananthan,

National Institute of Nutrition, India

*Correspondence: Ilkka Leinonen ilkka.leinonen@sruc.ac.uk

Specialty section: This article was submitted to Nutrition and Sustainable Diets, a section of the journal

Frontiers in Sustainable Food Systems

Received: 21 November 2018 Accepted: 04 April 2019 Published: 24 April 2019

Citation: Leinonen I, lannetta PPM, Rees RM, Russell W, Watson C and Barnes AP (2019) Lysine Supply Is a Critical Factor in Achieving Sustainable Global Protein Economy. Front. Sustain. Food Syst. 3:27. doi: 10.3389/fsufs.2019.00027
Production of animal-based protein is a significant global source of greenhouse gases, a major driver of agricultural land use and a source of nutrient loss to the environment. In this study, we provide a new assessment of the current sources of proteins in the human diet and analyze the options for increasing the use of plant-based sources, taking the protein quality, as indicated by the amino acid composition, into account. The results demonstrate the importance of sustainable global supply of lysine, one of the amino acids essential for human nutrition. It is demonstrated here that the current production of plant-based lysine that can be considered as replacement of lysine obtained from animal protein largely comes from soybean originating from a small number of countries. There are limited large-scale options to broaden the supply of plant-based lysine, namely increase of soya production outside its current main production areas, increase of production of legumes other than soya or other lysine-rich crops, obtaining plantbased lysine from sources not currently used for human consumption, or manufacturing lysine from non-standard plant-based sources (e.g., through fermentation from sugar). All of these options would require major changes in the structure of global agricultural production and associated agri-food systems and would especially have consequences on agricultural land use.

Keywords: amino acids, protein, food production, livestock, climate change, land use

\section{INTRODUCTION}

In order to achieve the targets of reducing greenhouse gas emissions and avoid dangerous climate change, urgent global actions are needed, as highlighted by the IPCC's recent Special Report (Intergovernmental Panel on Climate Change, 2018). One of the main sources of greenhouse gases is food production, and especially the livestock industry that currently provides a large part of the global protein supply for human consumption (Steinfeld et al., 2006; Nijdam et al., 2012). For this reason, shifting global consumption from animal-based to plant-based protein has been suggested as an effective way to reduce greenhouse gas emissions and other adverse environmental impacts (Pimentel and Pimentel, 2003; Westhoek et al., 2011; Aiking, 2014; Chaudhary et al., 2018; Intergovernmental Panel on Climate Change, 2018). Other benefits of large-scale replacement of animal protein by plant protein would be reduction in agricultural land use demand due to the higher efficiency of plant protein production, reduction in nutrient losses to the environment and improvements in human health (Shcherbak et al., 2014; Röös et al., 2016, 2017; Ascott et al., 2017; Altieri and Diaz, 2019; Zech and Schneider, 2019). 
Of the total global protein consumption by humans, the share of plant-based protein is currently about $60 \%$ and animal protein about 40\% (Boland et al., 2013; FAOSTAT, 2018). However, when considering alternative protein sources, it should be noted that the quantity of the protein alone is not a sufficient indicator of the potential to fulfill the nutritional demand of an increasing global population; protein quality and in particular its amino acid-balance must also be considered (Ritchie et al., 2018). The nutritional properties of animal- and plant-based proteins differ strongly. One of the most important properties of different protein sources is the concentration of certain essential amino acids that cannot be produced in the human body and therefore must be obtained from food (Lizarazo, 2015; Foyer et al., 2016). For example, amongst the main global food crops, many cereal species have a relatively low concentration of the essential amino acid lysine. Therefore, it is important that in plant-based diets, cereals are supplemented by other, lysine rich ingredients. Furthermore, it is important that the supply of all essential nutrients meets the demand of the world population. This is also the case for the nutritional profile of global protein production. In practice, this means that the global supply of all essential amino acids must meet the global demand.

The aim of this study was to analyze the global crop and livestock production data in order to identify options for more sustainable protein production in the future. The emphasis in the analysis was given to protein quality (i.e., amino acid concentration and amino acid balance) of different agricultural primary products. Based on this information, potential future transitions in the global protein production were explored, while considering the need to keep the supply of essential amino acids at the level of global demand, and taking also consequences for global need for agricultural land into account. In order to carry out such an analysis, global data on agricultural production is needed. For the purpose of this study, we decided to use the FAOSTAT (2018) database, because to our knowledge it would be the most comprehensive agricultural dataset available. Those data would cover practically all agricultural commodities in every region in the world, and the reported time series cover the period from 1960s until the present day. However, the data have also limitations. For example, it is not always possible to get accurate or "official" food production/supply data for certain countries, and therefore some data items are necessarily based on approximations and expert opinions (Ritchie et al., 2018). Another, limitation is that the magnitude of such uncertainties is difficult to quantify, and it is not reported on the FAOSTAT database. Nevertheless, we believe that this dataset is the best possible available for our analyses, and it would allow a reliable assessment of the magnitude of the global protein and amino acid production and supply, and allow assessing probable future availability of different protein sources.

\section{MATERIALS AND METHODS}

Annual (available from year 1961 to 2016) global, regional and country-specific data on the production (tons per year) of main crops, main land-based livestock species and edible animal products (animal carcass, milk, eggs) were obtained from the FAOSTAT food and agriculture database (FAOSTAT, 2018). The data on crop production consisted of more than 160 items. These included data on single major crops (e.g., "Soybeans," "Wheat," "Maize"), or product groups in the case of minor crops (e.g., "Cereals, not elsewhere specified," "Pulses, not elsewhere specified"). In addition to the production amounts, the yield (tons per hectare) of different crop species was obtained from the FAOSTAT database. This yield information was used in subsequent analyses to determine the land requirement of plant-based protein originating from different sources. The same database was also used for quantifying land-based animal products. Again, the data consisted of annual production figures (tons per year) of meat (specified by species or species groups, for example "Cattle," "Pigs," "Chicken," "Sheep," "Turkey," "Bird not elsewhere specified” etc.), milk (e.g., "Cow," "Buffalo”), eggs (e.g., "Hen," "Other bird"), and minor animal-based products such as honey.

The FAO production data were applied to quantify the production of total human edible protein and single human edible amino acids using the following calculation framework. First, the human-edible fraction of each of the crop and animal primary products was specified, based on data from the USDA food composition database (USDA, 2018) and other sources, including scientific literature (Ertl et al., 2015). In the case of minor products where data on the human edible fraction could not be found, this was assumed to be same as in similar products for which the data were available. Second, protein concentration of the human-edible fraction of each product was calculated, mainly based on data from the USDA food composition database and other sources including scientific literature (e.g., Mattila et al., 2002). In the case of products that were mainly intended for livestock feed, the Feedipedia (2018) database was used to determine the protein concentration. For product groups containing several single products (e.g., "Cereals, not elsewhere specified"), an average of other similar products was used as a protein concentration of the group in question. Third, the total global, regional and country-specific production (tons per year) of human edible protein was specified as follows:

$$
\operatorname{HEPr}_{i}=\operatorname{Prod}_{i} \times H E_{i} \times \operatorname{Pr}_{i}
$$

Where $H E P r_{i}$ is the annual production (tons per year, either global, regional or country-specific) of human edible protein from source $i$ (specified by crop species, product group or type of animal product), $\operatorname{Prod}_{\mathrm{i}}$ is the annual production (tons per year, global, regional or country-specific) of the protein source $i, H E_{\mathrm{i}}$ is the human edible fraction of the protein source $i$ and $P r_{\mathrm{i}}$ is the protein concentration of the protein source $i$. Finally, the total global production amounts of all plantbased human edible protein and land animal-based protein were obtained by aggregating the amounts of corresponding sourcespecific proteins.

Concentrations of essential amino acids (Isoleucine, Leucine, Lysine, Tryptophan, Threonine, Valine, Total sulfur amino acids, Total aromatic amino acids) were calculated using data from the USDA (2018) database, the Feedipedia (2018) database and 
other sources (e.g., Mattila et al., 2002). The "limiting" amino acids of each protein source were identified as follows. First, the daily human requirements of essential amino acids were obtained from the WHO recommendation (FAO/WHO/UNU, 2007). As an example, lysine requirement was determined to be $30 \mathrm{mg} \mathrm{kg}^{-1}$ (body weight) $\mathrm{d}^{-1}$ and sulfur amino acid requirement $15 \mathrm{mg}$ $\mathrm{kg}^{-1} \mathrm{~d}^{-1}$. Then, the total amount of protein from a specific origin (e.g., certain crop or animal product) needed to fulfill the daily requirement of each amino acid was calculated. This was done by dividing the recommended daily intake of each amino acid by the concentration of that specific amino acid in protein that originated from each food item. Finally, the specific amino acid that resulted in highest required total intake of protein for each food item was considered to be the first limiting amino acid in that product.

The global requirement of lysine (and other essential amino acids) was calculated (assuming a $70 \mathrm{~kg}$ average body weight) for the current population (7.6 billion) and for year 2050 projection of 9.7 billion, following a UK DESA 2015 report (UN DESA, 2015).

The total global, regional and country-specific production (tons per year) of each essential amino acid was specified as follows (lysine shown here as an example):

$$
\text { HELys }_{i}=\operatorname{Prod}_{i} \times H E_{i} \times \operatorname{Pr}_{i} \times L y s_{i}
$$

Where $H E L y s_{\mathrm{i}}$ is the annual production (tons per year, either global, regional or country-specific) of human edible lysine from source $i$ (specified by crop species, product group or type of animal product), $L y s_{\mathrm{i}}$ is the lysine concentration ( $\mathrm{g}$ lysine per g protein) of the protein source $i$ and other symbols are as in equation 1 .

In addition to the production of each protein source, the FAOSTAT (2018) data were used to calculate the country-specific daily per person lysine supply, and to determine its relation to the structure of the diet, i.e., the proportion of cereal based protein supply to protein supply from other sources. Since the FAO food supply data are less detailed than the production data, a simplified approach was used here. In this approach, the protein supply in each country was distributed to five categories, namely: (1) animal-based; (2) cereals; (3) oil crops (including soya and peanuts); (4) pulses (i.e., all other legumes except soya and peanut); and (5) all other crops. Then the lysine content for all these categories was determined as a weighted average based on the global production quantities and item-specific lysine concentrations (see above) of all food items belonging to each category.

\section{RESULTS AND DISCUSSION}

Based on the global food and agriculture data (FAOSTAT, 2018), the total production of human-edible plant-based protein was about $410 \mathrm{Mt}$ in 2016. This total is five times as high as the production of human edible protein originating from animalbased sources (livestock). However, comparison of the FAO statistics of global protein supply (FAOSTAT, 2018) to the FAO production data shows that the supply of plant-based protein for human consumption (130 Mt) is only 1.5 times as high as the supply of animal-based protein, indicating that the vast majority of human edible plant protein is actually used as animal feed.

It is important to note that not all of the apparently available $280 \mathrm{Mt}$ "unused" plant-based human edible protein can directly replace animal-based protein in human consumption. Analysis of the FAO data shows that current global production of potentially human edible plant protein is dominated by four crop species: soya, maize, wheat, and rice (Figure 1). However, it is generally acknowledged that of these crops, only soya (a leguminous species) is comparable to animal-based protein in terms of its amino acid composition, i.e., the ability to provide certain "limiting" amino acids to fulfill human requirements (Ferreira et al., 2005). In order to determine the quality of protein obtained from these crops as a potential source for human nutrition and to further assess the global production of essential amino acids, the first limiting amino acid and its concentration in protein originating from each of these crops was identified. This is demonstrated in Figure 2, where different protein sources are compared and the human-edible protein intake as determined by the limiting amino acid is shown. In addition to the main protein crops, broad beans and field peas (representing here other leguminous species than soya) as potential protein sources are also included the comparison. For simplicity, only those amino acid that are generally considered to be limiting in these crops (Ferreira et al., 2005; Moya, 2016) are shown in this figure, namely lysine, threonine, tryptophan (all potentially limiting in cereals), and sulfur amino acids (methionine and cysteine, potentially limiting in legumes). The result clearly shows that lysine is the limiting amino acid in all the main cereal species and sulfur amino acids in legumes. The relative importance of the low lysine concentration in cereals is also demonstrated by the fact that the concentration of the other essential amino acids included in the comparison is in most cereals mainly comparable to the legumes, which are generally considered to have a more "balanced" amino acid concentration. In other words, without the deficiency of lysine, approximately similar amounts of protein originating from either cereals or legumes would provide the same intake of essential amino acids, including threonine and tryptophan.

Further comparison of different food items in terms of their amino acid and energy concentration is presented in Figure 3. In this figure, the daily intake is presented separately for raw and cooked plant-based food items, since it is possible that the amino acid composition changes during cooking. These results show that in order to obtain the suggested daily amounts of these amino acids from soya or animal proteins, only about half of the suggested daily protein intake is needed, and the remaining protein could be obtained from other plant-based foods which would also provide other essential nutrients and energy. In contrast, in order to obtain the minimum amount of lysine from cereals, the required total protein intake would exceed the daily recommended intake. Further in the comparison, broad bean is used as an example of alternative leguminous food (Figure 3A). Although the lysine concentration of this species is comparable to soya, as demonstrated above, beans are low in sulfur amino acids, meaning that a higher total protein intake is needed to obtain 

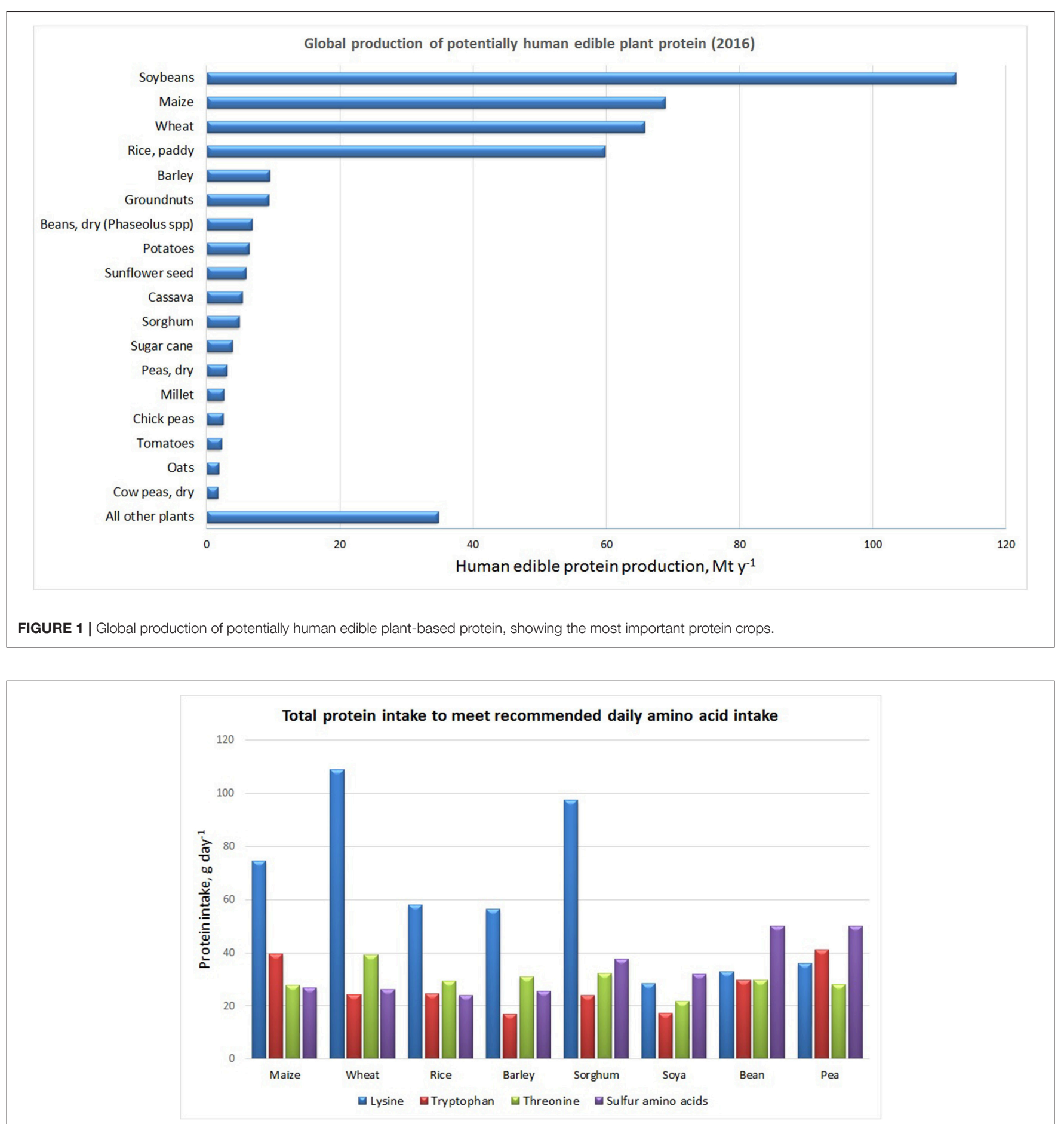

FIGURE 2 | Protein obtained from selected crops corresponding to an amount that would fulfill the daily amino acid requirements of a $70 \mathrm{~kg}$ adult. Each of the potentially limiting amino acids (lysine, tryptophan, threonine, and sulfur amino acids) is considered separately. The amino acid with the highest required protein intake indicates the first limiting amino acid in each product.

the recommended amount of these compared with soya and animal protein. However, it should be noted that a combination of beans (or other legumes) and cereals will make the overall amino acid content more balanced and therefore reduce the total protein intake required, which is also demonstrated in Figure 3A. It can also be seen that although there are some differences in the amino acid concentration between raw and cooked food items, those differences did not change the main 


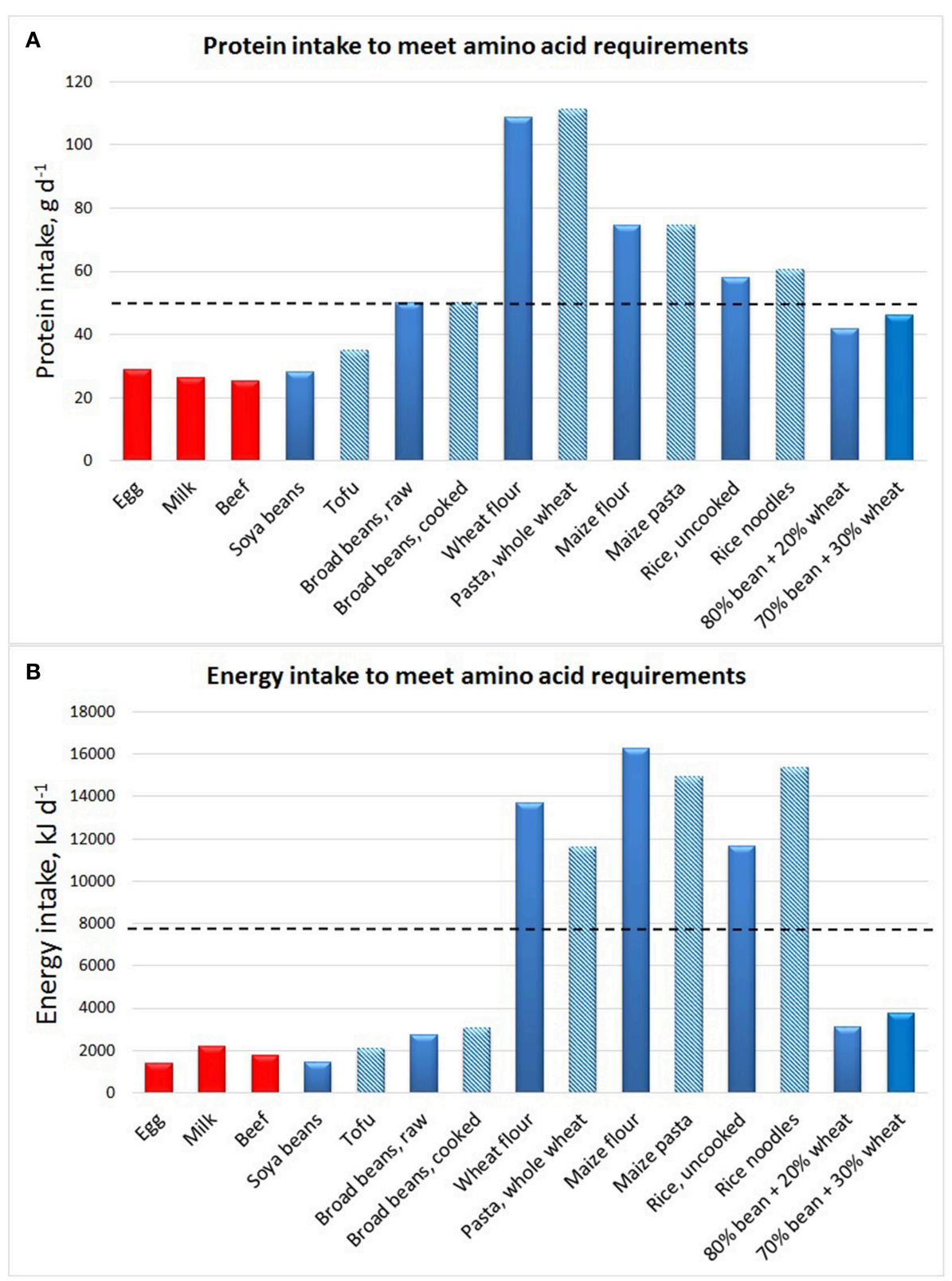

FIGURE 3 | Protein (A) and energy (B) obtained from selected food items corresponding to an amount that would fulfill the daily lysine and sulfur amino acid requirements of a $70 \mathrm{~kg}$ adult. The red bars indicate animal products, blue bars plant-based products and shaded bars cooked products. The horizontal broken lines indicate the recommend daily intake of total protein and energy. The figure shows that having cereals as the primary lysine source would lead to overconsumption of energy and protein. The combinations of beans and wheat indicate the protein and energy intakes when either 70 or $80 \%$ of the daily lysine requirement is obtained from broad beans and the rest from whole grain wheat.

conclusion, according to which much higher cereal protein intake is needed compared to animal proteins and soya, to fulfill the daily lysine requirement. However, it should be noted that some of the total protein content of the raw food ingredients is likely to be lost in cooking, and therefore slightly higher amounts of the protein in raw foods would be needed to fulfill the amino acid requirements than indicated in the figure. Such losses are likely to vary strongly depending on the cooking methods, and for that reason we did not try to quantify them in this specific study.

In addition to the variation in the amino acid concentration in different food items, also the protein/energy ratio has a strong effect on their nutritional quality. Figure 3B shows the amount of daily energy intake obtained from different food items corresponding to the protein intake shown in Figure 3A. This demonstrates that having cereals as the main source of essential 


\section{Country-specific lysine intake}

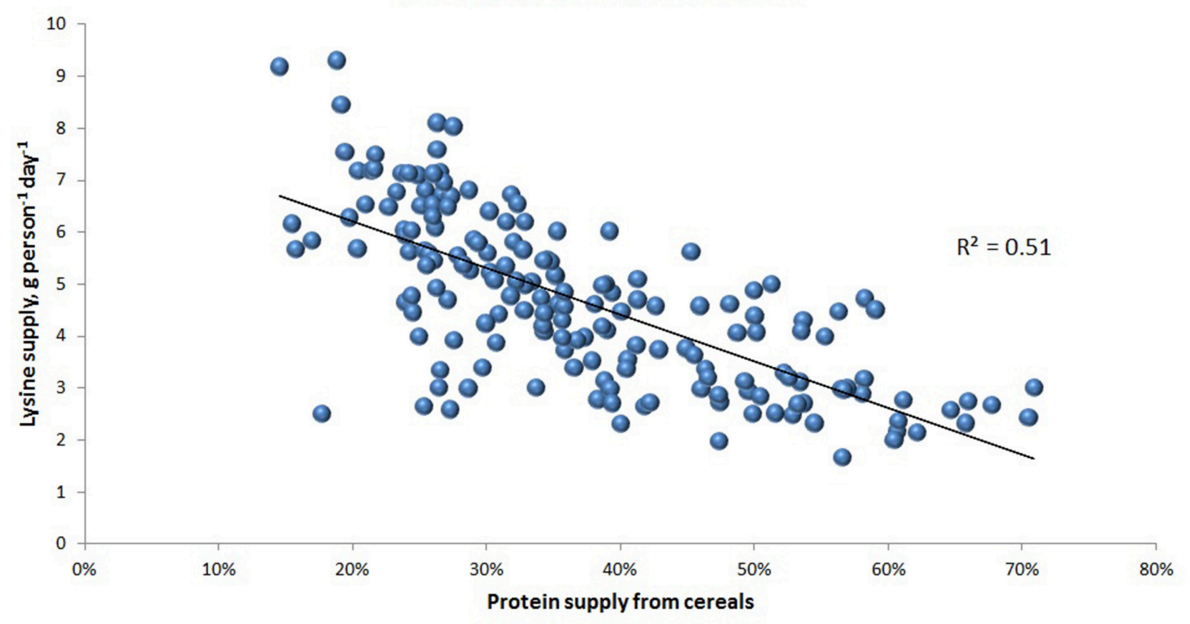

FIGURE 4 | Empirical relationship between the proportion of cereal-based proteins in the protein supply and the daily per person lysine supply in different countries. Based on the FAOSTAT (2018) food supply data and the USDA (2018) nutrition database.

amino acids (especially lysine) will lead either to vast excess of daily energy intake, or alternatively a deficit of lysine, making it difficult to supplement the diet with other food items that would provide nutrients not available from cereals.

The empirical relationship between the composition of diet and lysine intake at the global level is further demonstrated in Figure 4. Based on the FAOSTAT food supply data and the protein and lysine concentrations in specific food item groups, the correlation between the proportion of cereal-based proteins and the daily per person lysine supply in different countries included in the FAO dataset is shown in the figure. It can be seen that there is a clear negative correlation between the lysine supply and the proportion of the protein obtained from cereals. There are two main reasons for this trend. First, in many lowincome countries where the overall protein supply is limited, it is likely that this supply is concentrated to low cost protein sources, such as cereals. Second, as demonstrated above, the lysine concentration in cereals is low and therefore relying mainly on this source in protein intake would make it very difficult to achieve the recommended daily lysine intake. As a result, in countries with very high proportion of cereal-based protein supply, the average per person lysine intake is approaching the limit of lysine deficit (the WHO daily recommendation for a $70 \mathrm{~kg}$ person is $2.1 \mathrm{~g}$ per day). In such countries, it is likely that a large part of the population and especially growing children are consuming a diet that does not provide enough lysine (Moya, 2016). It should be also noted that although the general trend in Figure 4 is rather clear, there is a lot of scatter and several countries deviate from this trend. For example, in some Sub-Saharan African countries the proportion of cereals in the diet and the lysine intake are both relatively low. In the case of those countries, the reason for low lysine intake is the low level of protein supply in general, rather than high intake of cereal protein. In contrast, in some Northern African countries, such as Morocco and Egypt, both the level of lysine intake and the proportion of cereals in diet are high. The main reason for this is that in those specific countries there is a high proportion of animal protein in the diet, in addition to high level of cereals.

Compared to overall plant protein production (Figure 1), the production of plant-based lysine is even more concentrated in a small number of commodities. Soya is by far the most important source of plant-based lysine (Figure 5), exceeding the amount of total cereal-based lysine produced by about $2 \mathrm{Mt}$ per year. However, based on the FAO statistics (FAOSTAT, 2018) on global food supply and the estimated lysine concentration of soya protein, only about $0.25 \mathrm{Mt}$ soya-based lysine (i.e., 3\% of the total production) is supplied for human consumption and the rest is used as animal feed. Keeping in mind that cereal protein is not suitable as a primary lysine source (as demonstrated in Figure 3), it is clear that global human nutrition is currently largely dependent on animal-based lysine. It can be also seen that the current total global production of lysine from land-based animals is actually of a similar magnitude to the total lysine demand from the global human population (Figure 5).

Based on the current production figures, it is quite obvious that the options for replacing animal-based lysine with plantbased lysine sources at the global level (and considering also the increasing demand as a result population growth) within a timeframe of the next decades are rather limited. As indicated by the analysis shown above, cereals cannot be used as a primary lysine source but rather as a supplement to high-lysine plant proteins. Although some increase in the lysine concentration of cereals can be achieved through plant breeding (Jiang et al., 2008; Yu and Tian, 2018), due to biological constraints and the time requirements for breeding programs, there will be no rapid solution to the lysine problem through the route of genetic selection in the case of most of the cereals (Ferreira et al., 2005; Wang and Galili, 2016). However, there is one exception, namely so called Quality Protein Maize (QPM, for an overview, see 


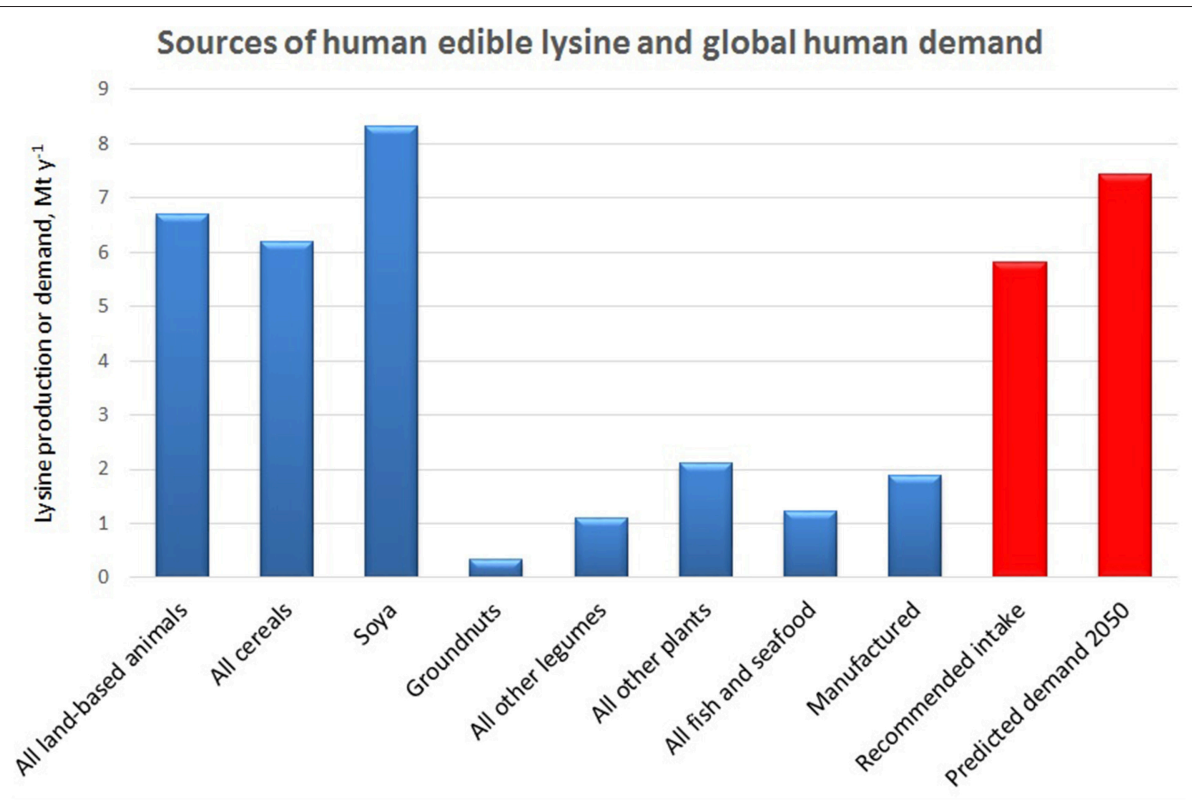

FIGURE 5 | Global production of potentially human edible lysine from animal products, soya, groundnuts, all other legumes, all cereals, all other plant-based protein (FAOSTAT, 2018) and other sources [manufactured lysine, according to 2014 data (Global Market Insights, 2015; Grand View Research, 2015)]. The estimate for fish and seafood is based on the FAOSTAT protein supply data (FAOSTAT, 2018), as global production data were not available in the FAO statistics. The current global demand for human consumption based on intake recommendations and the estimated demand in 2050, following the predicted population growth, are also shown.

Prasanna et al., 2001). This maize variety has been observed to have a lysine concentration as high as around $4.5 \%$ of the total protein (Mbuya et al., 2011), while in standard maize this concentration is well below 3\% (a value of 2.8\% was used in the current analysis, based on the USDA database). The use of such varieties would considerably improve the value of maize as a protein source, although it could still not match the value of animal protein or legumes. However, according to Tandzi et al. (2017), the area of the global QPM production is 3.5 million hectares, which is only less that $2 \%$ of the production area of standard maize. One of the reason for the limited use of GPM is the lower yield compared to the standard maize. So it is unlikely that increasing use of this variety will have major short-term impact on the global lysine supply, but it could have a significant improvement of local lysine availability for example in some low-income African countries. It should also be noted that there is research going on aiming to apply transgenic techniques in order to increase the lysine concentration also in other cereals in addition to maize (Moya, 2016; Wang and Galili, 2016). However, it is not known when such transgenic lines would be commercially available, so it is unclear if they could significantly affect the global lysine supply in the near future.

Due to uncertainties related to the progress of adopting new crop varieties and novel breeding techniques, it is likely that soya and other legumes (and possibly other currently available lysine-rich crops) will remain as the only globally available potential primary source of plant-based lysine at present and in the near future. Considering these limitations, future scenarios for solving the lysine puzzle are more or less limited to four options, namely: (1) transferring more soya protein to human consumption; (2) increasing the production of legumes other than soya, or other lysine-rich crops; (3) obtaining plant-based lysine from sources not currently used for human consumption (e.g., oilseed production); or, (4) manufacturing lysine from non-standard plant-based sources (e.g. through fermentation from sugar). All of these options have their benefits but also serious challenges.

Current levels of soya protein production are high enough to replace all protein (and all lysine) in the human diet that is currently produced by animals. Although only relatively small quantities of soya are currently used for human nutrition at the global scale, directing a higher proportion of soya protein from animal feed to human consumption is likely to be achievable in a short timescale. Such change would require a reduction of non-ruminant animal protein production (e.g., pig meat, chicken meat, and chicken eggs) in particular. Pigs and chickens (similarly to humans) cannot produce lysine and therefore are dependent on external lysine sources. That is also the reason why the non-ruminant livestock industry is the main consumer of currently available soya protein. Based on the FAOSTAT (2018) database, the human edible lysine obtained from non-ruminant livestock is $3.5 \mathrm{Mt} \mathrm{y}^{-1}$, which is about half of the total lysine available from land animal-based products. Replacement of this amount of animal-based lysine by lysine obtained from soya would therefore need less than half of the currently available soya protein. That would allow more than 50 million hectares (based on the global average yield data of soya) of land currently used for soya production to be used for other purposes, for example further food production needed for a growing human population 


\section{Regional production of soya-based lysine}

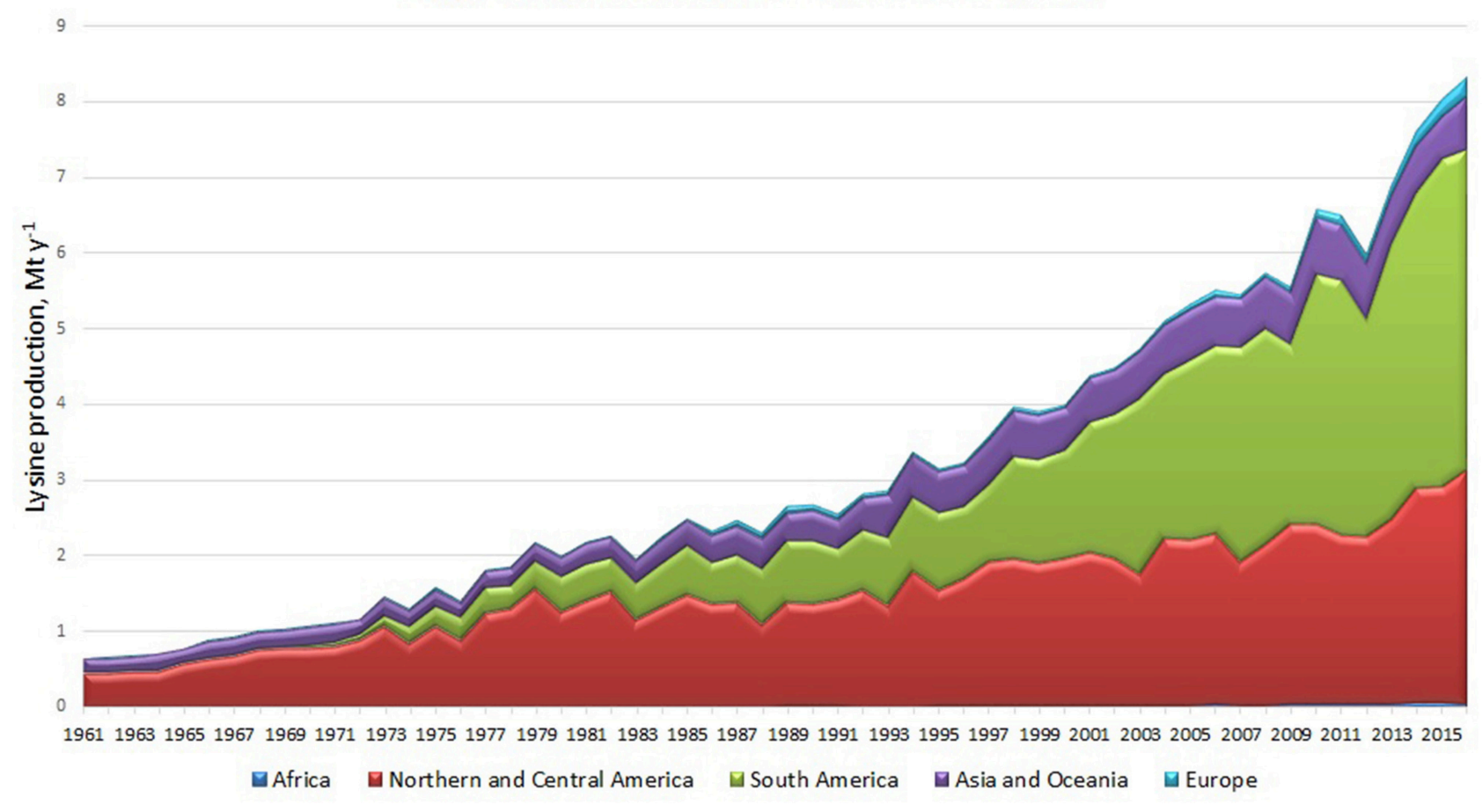

FIGURE 6 | Regional production of soya-based lysine $\left(\mathrm{Mt} \mathrm{y}^{-1}\right)$ between 1961 and 2016. The two dominant areas of current production are South America (predominantly Brazil and Argentina) and North America (predominantly USA).

(see Figure 5), or carbon sequestration through reforestation. However, it should be noted that soya beans are also the main source of global vegetable oil production. Therefore, reducing the area of soya cultivation would lead to increasing demand for other oil crops.

The dependence on soya as the single crop species providing lysine for humans (or livestock) is not without problems. Over recent decades, the production of soya has increasingly concentrated in two regions, South America and North America (Figure 6). In fact, $80 \%$ of the world's soybeans are produced in just three countries; USA, Brazil and Argentina. This soya dependency has some serious consequences for global food security that have been already recognized for example in the European Strategy for the Promotion of Protein Crops (Fader et al., 2013; European Parliament, 2018). Therefore, options for large scale production of protein crops outside the Americas need to be urgently considered. In the case of human edible lysine production, these options would in practice be limited to producing soya outside its current cultivation area, and increasing the cultivation, aggregation, and processing capacities for other grain legumes.

Introducing soya cultivation to new areas is complex. For example, although high yields of soya have been reached in Southern Europe, there have been no increasing trends in production of this commodity in that area in recent years. In 2016, the total South European soya bean-based lysine production was only about $0.05 \mathrm{Mt}$, i.e., $0.6 \%$ of the global soya-based lysine production. In addition, there are regions such as Northern Europe, where soya production is limited by climate, and production in Central Europe has also been found to be challenging for example due to susceptibility to diseases and problems in intercropping (Zimmer et al., 2016).

If the area of soya cultivation is not significantly expanded, supply of plant-based lysine produced outside North and South America would necessarily be based on other leguminous or other lysine-rich crops. In general, other legumes have been considered to be better than soya for the environment in terms of their nitrogen contribution to farming systems through rotations, intercropping, non-cropped diversity and diversification to reduce agrochemical dependency. In terms of lysine supply, the two dominant leguminous crops other than soya are currently beans (Phaseolus L. spp.) and groundnuts (although a major part of this crop is currently used for oil production), producing 0.40 and $0.33 \mathrm{Mt}$ lysine per year, respectively. Other major legumes include peas (Pisum sativum L.) and chickpeas with lysine production 0.20 and $0.16 \mathrm{Mt}$ per year, respectively. The problem with all these species is that their lysine yield per hectare is much lower than that in soya; to replace 1 ha soya to obtain the same amount of lysine, based on the global average yields, requires 5.5 ha groundnuts, 5.3 ha (Phaseolus spp.) beans, 3.0 ha peas or 5.5 ha chickpeas. This would mean that large scale replacement of soya by other leguminous species to produce protein (and especially lysine) could necessarily lead to increasing land use pressure. It should also be noted that amongst the minor 
leguminous species, broad beans (Vicia faba L.) have a relatively high yields; only 2.3 ha broad beans is needed to replace 1 ha of soya. However, currently the global production of broad beanbased lysine is only $0.07 \mathrm{Mt}$, equaling $<1 \%$ of global soya-based lysine production.

In addition to legumes, there are also other crops with high lysine concentration. These include so called pseudocereals such as buckwheat, quinoa, and amaranth. However, the current production quantities of these crops are very low and regionally restricted, and it is unlikely that they would become a large global source of lysine in the future. The current global production of lysine originating from buckwheat and quinoa is only 0.15 and $0.01 \%$, respectively, compared to the global production of soya-based lysine. Amaranth cultivation is considered to have only local importance, and data on amaranth production is not included in the FAO statistics (Arendt and Zannini, 2013). Another limiting factor of pseudocereal production is their low yields. To produce the amount of lysine that would replace 1 ha soya cultivation, 13 ha buckwheat and 14 ha quinoa would be needed, based on their average global yields. For amaranth, no global yield statistics exist, but assuming a typical seed yield of 2 $\mathrm{t} / \mathrm{ha}$, (Arendt and Zannini, 2013) the area of amaranth cultivation to replace 1 ha of soya would be $5.5 \mathrm{ha}$.

When considering the option of improving the utilization of other plant-based proteins that are currently not used for human consumption, oilseed rape is probably the most realistic candidate to be used as a human protein source. In terms of its current use, rapeseed is very similar to soya; it is the world's second most important vegetable oil crop, after soya, and the protein obtained as a by-product from this crop is mainly used as animal feed. Also the amino acid composition of rapeseed is comparable to soya, making it a valuable livestock feed supplement (Shahidi, 1990). The total amount of rapeseed-based lysine produced annually is $0.8 \mathrm{Mt}$, but none of this can be currently considered suitable for human consumption, due to various antinutritional issues. There are attempts to overcome problems related to human use of rapeseed protein e.g., by developing protein extraction methods (Yoshie-Stark et al., 2006; Von Der Haar et al., 2014; Chéreau et al., 2016). Although some rapeseed protein can potentially be made available for human consumption in the future, the quantity of rapeseed produced is not sufficient to make it viable as a global substitute for soya at the present time.

A completely different approach to the global lysine problem would be to produce lysine from other primary sources than plant or animal protein. This is already happening, as considerable amounts of lysine are manufactured through fermentation, using mainly sugars and inorganic nitrogen as raw materials. This product is currently almost entirely used as a feed supplement, partly replacing soybean meal. Current production costs of manufactured lysine are low enough to make its use competitive with soya for livestock feed. The annual production of manufactured lysine was 1.9 Mt in 2014 (Figure 5) and this is expected to double by 2020, according to industry reports (Global Market Insights, 2015; Grand View Research, 2015). This production figure is higher than the amount of lysine originating from all currently produced legumes, excluding soya. Manufactured lysine is a serious candidate as a global-scale amino acid supply in human nutrition, because the technology for its production is readily available. This process does not need any "traditional" protein crops as a raw material, which would substantially increase the flexibility of land use in protein production for human consumption. Based on the calculations by Mosnier et al. (2011), the land area needed to produce the raw materials for $1 \mathrm{t}$ of manufactured lysine would be only 0.3 ha. This would mean a minimal land use requirement compared to land needed to obtain the same amount of lysine from protein crops, for example soya (15 ha), broad beans (33 ha), peas (44 ha), Phaseolus spp. beans (77 ha), buckwheat (185 ha), or quinoa (203 ha), based on the global FAOSTAT (2018) yield data. As a result, using manufactured lysine as a supplement in human food would allow a huge saving in the use of global agricultural land that would otherwise be needed for the production of plant or animal-based protein. However, it should be noted that if the lysine intake by humans was largely based on supplements, it would be necessary to ensure that the diet also contains other essential amino acids, obtained from other protein sources.

As a conclusion, the results of this study show that currently available protein sources that can also be considered as primary sources of lysine are largely limited to animal products (together with soybeans that are currently almost entirely used as animal feed). For this reason, the proposed radical reduction of consumption of animal-based protein in order to limit the global warming (Intergovernmental Panel on Climate Change, 2018) looks rather problematic, as it brings serious challenges in meeting global nutritional demand. Although some recent studies suggest otherwise (Ritchie et al., 2018) we found that the current production of plant based protein can technically meet the global lysine demand if the current production level of soya is maintained and targeted at human consumption. However, for a variety of reasons, including the regionally concentrated production and various environmental issues (Guo and Gifford, 2002; WWF, 2012), soya may not be considered as a sustainable solution to the lysine puzzle.

Replacing animal protein and soya with other lysine-rich protein crops (the production quantities of which are currently very low compared to global demand of lysine) would need major changes in the structure of global agri-food systems. Such changes would necessarily differ strongly regionally, due to limitations in climate and soil conditions, socio-economic conditions and cultural issues. Furthermore, in many regions, plant protein production may still need to be restricted to low quality or non-human edible protein that can only be utilized as livestock feed. One future option for more sustainable human nutrition could be large scale use of manufactured lysine as a food supplement, in combination with an increase and diversification of legume-based cropping systems. Although manufactured lysine may have problems in terms of social acceptability, it is likely to be a more realistic future nutrient source than suggested alternatives such as cultivated meat (Edelman et al., 2005; Tuomisto and de Mattos, 2011), especially when considering the price and time taken for it to become available for the majority of 
consumers. Following the alarming report of Intergovernmental Panel on Climate Change (2018) it is clear that urgent actions are needed to limit climate change, including changes in global food consumptions and production. For such rapid changes to take effect, it will be necessary to rely largely on the application of existing technologies and on the redesign of current agricultural production systems.

Agricultural production is heavily subsidized across most Western developed countries and, for the last few decades, has switched more support to achieving wider ecological goals. Whilst currently nutritional benefits are not explicit within these mechanisms they provide strong leverage for incentivizing availability of specific lysine-rich protein crops through, for example agri-environmental schemes. In addition, stimulating demand for lysine within those converting to a plant based diet can emerge through information and health campaigns for creating wider knowledge on amino acid intake. The reduction in costs from stimulating production and, in parallel, growing demand may be a further incentive for agri-food supply chains to innovate within these emerging markets.

The importance of increasing production of protein crops is recognized in the European Commission (2018) report on the development of plant proteins in the European Union. Interestingly, this report does not specifically mention lysine, other essential amino acids, or the protein quality in general. Instead, it focuses on "protein rich plants," which include legumes, but also non-human edible protein e.g., oilseed rape. However, the report specifies various environmental benefits of increasing cultivation of high-protein legumes (which are also high in lysine). According to this report, there are numerous existing policy instruments in the EU that can "further strengthen and develop EU-grown plant proteins." The report lists the following options: (1) Support farmers

\section{REFERENCES}

Aiking, H. (2014). Protein production: planet, profit, plus people? Am. J. Clin. Nutr. 100(Suppl. 1), 483S-489S. doi: 10.3945/ajcn.113.071209

Altieri, A. H., and Diaz, R. J. (2019). "Dead zones: oxygen depletion in coastal ecosystems, in world seas: an environmental evaluation," in Ecological Issues and Environmental Impacts, Vol. 3, ed C. Sheppard (Cambridge, MA: Academic Press), 453-473.

Arendt, E. K., and Zannini, E. (2013). Cereal Grains for the Food and Beverage Industries. Cambridge: Woodhead Publishing Limited. doi: 10.1533/9780857098924

Ascott, M. J., Gooddy, D. C., Wang, L., Stuart, M. E., Lewis, M. A., Ward, R. S., et al. (2017). Global patterns of nitrate storage in the vadose zone. Nat. Commun. 8:1416. doi: 10.1038/s41467-017-01321-w

Boland, M. J., Rae, A. N., Vereijken, J. M., Meuwissen, M. P. M., Fischer, A. R. H., van Boekel, M. A. J. S., et al. (2013). The future supply of animalderived protein for human consumption. Trends Food Sci. Tech. 29, 62-73. doi: 10.1016/j.tifs.2012.07.002

Chaudhary, A., Gustafson, D., and Mathys, A. (2018). Multi-indicator sustainability assessment of global food systems. Nat. Commun. 9:848. doi: 10.1038/s41467-018-03308-7

Chéreau, D., Videcoq, P., Ruffieux, C., Pichon, L., Motte, J.-C., Belaid, S., et al. (2016). Combination of existing and alternative technologies to promote oilseeds and pulses proteins in food applications. OCL 23:D406. doi: $10.1051 / \mathrm{ocl} / 2016020$ growing plant proteins via the proposed future EU Common Agricultural Policy, by including them in national Common Agricultural Policy strategic plans, (2) Increase competitiveness of protein crops through Research \& Innovation (e.g., through EU and Member States' research programs), (3) Improve market analysis and transparency (e.g., improving data on prices, trade flows, and production/consumption), (4) Promote the benefits of plant protein for nutrition, health, climate, and environment, e.g., by using EU promotion programs, fairs, social media, and school schemes, and (5) Increase sharing of knowledge and best practice in supply chain management and sustainable agronomic practices. All these policy instruments can be applied at regional and national level in the future, not only to promote the quantity of the protein produced, but potentially also the quality of the protein, with the main emphasis on balanced amino acid concentration to provide sufficient supply of all essential amino acids for the demand of human population.

\section{AUTHOR CONTRIBUTIONS}

IL designed the structure of the paper, carried out the data analysis and led the writing process. All authors (IL, PPMI, RMR, $\mathrm{WR}, \mathrm{CW}$, and $\mathrm{APB}$ ) contributed to writing.

\section{FUNDING}

This study was funded by the Scottish Government SEFARI Gateway project, Pathways toward a sustainable protein economy. Author institutions are supported by the Scottish Government's Strategic Research Programme, and PPMI and RMR are also supported by the EU-H2020 funded project TRUE (www.true-project.eu), Grant Agreement number 727973.

Edelman, P. D., McFarland, D. C., Mironov, V. A., and Matheny, J. G. (2005). Commentary: in vitro-cultured meat production. Tissue Eng. 11:659. doi: 10.1089/ten.2005.11.659

Ertl, P., Klocker, H., Hörtenhuber, S., Knaus, W., and Zollitsch, W. (2015). The net contribution of dairy production to human food supply: the case of Austrian dairy farms. Agr. Syst. 137, 119-125. doi: 10.1016/j.agsy.2015.04.004

European Commission (2018). Report from the Commission to the Council and the European Parliament on the Development of Plant Proteins in the European Union. $\operatorname{COM(2018)} 757$ Final. Available online at: https://ec.europa.eu/ agriculture/cereals/development-of-plant-proteins-in-europe_en (accessed November 30, 2018).

European Parliament (2018). Report on a European Strategy for the Promotion of Protein Crops - Encouraging the Production of Protein and Leguminous Plants in the European Agriculture Sector (2017/2116(INI)). Committee on Agriculture and Rural Development, European Parliament. Available online at: http:// www.europarl.europa.eu/sides/getDoc.do?pubRef=-//EP//NONSGML\$+ \$REPORT\$+\$A8-2018-0121\$+\$0\$+\$DOC\$+\$PDF\$ \$V0//EN (accessed November 19, 2018).

Fader, M., Gerten, D., Krause, M., Lucht, W., and Cramer, W. (2013). Spatial decoupling of agricultural production and consumption: quantifying dependences of countries on food imports due to domestic land and water constraints. Environ. Res. Lett. 8:014046. doi: 10.1088/1748-9326/8/1/014046

FAO/WHO/UNU (2007). Protein and Amino Acid Requirements in Human Nutrition. Report of a Joint FAO/WHO/UNU Expert Consultation (WHO Technical Report Series 935). Available online at: http://www.who.int/ 
nutrition/publications/nutrientrequirements/WHO_TRS_935/en/ (accessed November 19, 2018).

FAOSTAT (2018). Food and Agriculture Data. The Food and Agriculture Organization of the United Nations (FAO). Available online at: http://www.fao. org/faostat/en/ (accessed November, 19, 2018).

Feedipedia (2018). Animal Feed Resources Information System. Available online at: https://www.feedipedia.org/ (accessed November 19, 2018).

Ferreira, R. R., Varisi, V. A., Meinhardt, L. W., Lea, P. J., and Azevedo, R. A. (2005). Are high-lysine cereal crops still a challenge? Braz. J. Med. Biol. Res. 38, 985-994. doi: 10.1590/S0100-879X2005000700002

Foyer, C. H., Lam, H. M., Nguyen, H. T., Siddique, K. H., Varshney, R. K., Colmer, T. D., et al. (2016). Neglecting legumes has compromised human health and sustainable food production. Nat. Plants 2:16112. doi: $10.1038 /$ nplants.2016.112

Global Market Insights (2015). Lysine, Methionine Market Size for Animal Nutrition, Potential, Industry Outlook, Regional Analysis (U.S., Germany, UK, Italy, Russia, China, India, Japan, South Korea, Brazil, Mexico, Saudi Arabia, UAE, South Africa), Application Development, Competitive Landscape \& Forecast, 2016 - 2023. Available online at: https://www.gminsights.com/ industry-analysis/lysine-methionine-market (accessed November 19, 2018).

Grand View Research (2015). Lysine Market Analysis by Application (Animal Feed, Food \& Dietary Supplements, Pharmaceuticals), by Livestock (Swine, Poultry) and Segment Forecasts to 2020. Available online at: https://www. grandviewresearch.com/press-release/global-lysine- market

Guo, L. B., and Gifford, R. M. (2002). Soil carbon stocks and land use change: a meta analysis. Glob. Chang. Biol. 8, 345-360. doi: 10.1046/j.1354-1013.2002.00486.x

Intergovernmental Panel on Climate Change (2018). Global Warming of $1.5^{\circ} \mathrm{C}$. Available online at: http://www.ipcc.ch/report/sr15/ (accessed November 19, 2018).

Jiang, X., Tian, J., Hao, Z., and Zhang, W. (2008). Protein content and amino acid composition in grains of wheat-related species. Agr. Sci. China 7, 272-279. doi: 10.1016/S1671-2927(08)60066-8

Lizarazo, C. I. (2015). Nutritive quality and protein production from grain legumes in a boreal climate. J. Sci. Food Agric. 95, 2053-2064. doi: 10.1002/jsfa.6920

Mattila, P., Salo-Väänänen, P., Könkö, K., Aro, H., and Jalava, T. (2002). Basic composition and amino acid contents of mushrooms cultivated in Finland. J. Agric. Food Chem. 50, 6419-6422. doi: 10.1021/jf020608m

Mbuya, K., Nkongolo, K. K., and Kalonji-Mbuyi, A. (2011). Nutritional analysis of quality protein maize varieties selected for agronomic characteristics in a breeding program. Int. J. Plant. Breed. Genet. 5, 317-327. doi: 10.3923/ijpbg.2011.317.327

Mosnier, E., van der Werf, H. M. G., Boissy, J., and Dourmad, J.-Y. (2011). Evaluation of the environmental implications of the incorporation of feed-use amino acids in the manufacturing of pig and broiler feeds using Life Cycle Assessment. Animal 5, 1972-1983. doi: 10.1017/S1751731111001078

Moya, M. (2016). Lysine genetically enriched cereals for improving nutrition in children under 5years in low- and middle- income countries. J. Nutr. Health Food Eng. 5, 583-586. doi: 10.15406/jnhfe.2016.05.00164

Nijdam, D., Rood, T., and Westhoek, H. (2012). The price of protein: review of land use and carbon footprints from life cycle assessments of animal food products and their substitutes. Food Policy 37, 760-770. doi: 10.1016/j.foodpol.2012.08.002

Pimentel, D., and Pimentel, M. (2003). Sustainability of meat-based and plantbased diets and the environment. Am. J. Clin. Nutr. 78(3 Suppl.), 660S-663S. doi: 10.1093/ajcn/78.3.660S

Prasanna, B. M., Vasal, S. K., Kassahun, B., and Singh, N. N. (2001). Quality protein maize. Curr. Sci. 81, 1308-1319.

Ritchie, H., Reay, D. S., and Higgins, P. (2018). Beyond calories: a holistic assessment of the global food system. Front. Sust. Food Syst. 2:57. doi: 10.3389/fsufs.2018.00057

Röös, E., Bajželj, B., Smith, P., Patel, M., Little, D., and Garnett, T. (2016). Protein futures for Western Europe: potential land use and climate impacts in 2050. Reg. Environ. Change 17, 367-377. doi: 10.1007/s10113-0161013-4

Röös, E., Bajželj, B., Smith, P., Patel, M., Little, D., and Garnett, T. (2017). Greedy or needy? Land use and climate impacts of food in 2050 under different livestock futures. Glob. Environ. Change 47, 1-12. doi: 10.1016/j.gloenvcha.2017. 09.001

Shahidi, F. (1990). Canola and Rapeseed: Production, Chemistry, Nutrition and Processing. London: Chapman and Hall.

Shcherbak, I., Millar, N., and Robertson, G. P. (2014). Global metaanalysis of the nonlinear response of soil nitrous oxide (N2O) emissions to fertilizer nitrogen. PNAS 111:9199. doi: 10.1073/pnas.1322434111

Steinfeld, H., Gerber, P., Wassenaar, T., Castel, V., Rosales, M., and de Haan, C. (2006). Livestock's Long Shadow: Environmental Issues and Options. Rome: FAO.

Tandzi, L. N., Mutengwa, C. S., Ngonkeu, E. L. M., Woïn, N., and Gracen, V. (2017). Breeding for quality protein maize (QPM) varieties: a review. Agronomy 7:80. doi: 10.3390/agronomy7040080

Tuomisto, H. L., and de Mattos, M. J. (2011). Environmental impacts of cultured meat production. Environ. Sci. Technol. 45, 6117-6123. doi: 10.1021/ es200130u

UN DESA (2015). World Population Prospects: The 2015 Revision. UN DESA Report. Available online at: http://www.un.org/en/development/desa/news/ population/2015-report.html (accessed November 19, 2018).

USDA (2018). Food Composition Databases. United States Department of Agriculture, Agricultural Research Service. Available online at: https://ndb.nal. usda.gov/ndb/ (accessed November 19, 2018).

Von Der Haar, D., Müller, K., Bader-Mittermaier, S., and Eisner, P. (2014). Rapeseed proteins - Production methods and possible application ranges. OCL 21:D104. doi: 10.1051/ocl/2013038

Wang, W., and Galili, G. (2016). Transgenic high-lysine rice - a realistic solution to malnutrition? J. Exp. Bot. 67, 4009-4011. doi: 10.1093/jxb/erw254

Westhoek, H., Rood, T., van de Berg, M., Janse, J., Nijdam, D., Reudink, M., et al. (2011). The Protein Puzzle. The Consumption and Production of Meat, Dairy and Fish in the European Union. The Hague: PBL Netherlands Environmental Assessment Agency.

WWF (2012). Soya and the Cerrado: Brazil's Forgotten Jewel. WWF Report UK 2011. Available online at: http://assets.wwf.org.uk/downloads/soya_and_the_ cerrado.pdf (accessed November 19, 2018).

Yoshie-Stark, Y., Wada, Y., Schott, M., and Wäsche, A. (2006). Functional and bioactive properties of rapeseed protein concentrates and sensory analysis of food application with rapeseed protein concentrates. LWT 39, 503-512. doi: 10.1016/j.lwt.2005.03.006

Yu, S., and Tian, L. (2018). Breeding major cereal grains through the lens of nutrition sensitivity. Mol. Plant 11, 23-30. doi: 10.1016/j.molp.2017.08.006

Zech, K. M., and Schneider, U. M. (2019). Technical biofuel production and GHG mitigation potentials through healthy diets in the EU. Agr. Syst. 168, 27-35. doi: 10.1016/j.agsy.2018.10.004

Zimmer, S., Messmer, M., Haase, T., Piepho, H.-P., Mindermann, A., Schulz, H., et al. (2016). Effects of soybean variety and Bradyrhizobium strains on yield, protein content and biological nitrogen fixation under cool growing conditions in Germany. Eur. J. Agron. 72, 38-46. doi: 10.1016/j.eja.2015. 09.008

Conflict of Interest Statement: The authors declare that the research was conducted in the absence of any commercial or financial relationships that could be construed as a potential conflict of interest.

Copyright (c) 2019 Leinonen, Iannetta, Rees, Russell, Watson and Barnes. This is an open-access article distributed under the terms of the Creative Commons Attribution License (CC BY). The use, distribution or reproduction in other forums is permitted, provided the original author(s) and the copyright owner(s) are credited and that the original publication in this journal is cited, in accordance with accepted academic practice. No use, distribution or reproduction is permitted which does not comply with these terms. 